\title{
PERAN GENDER DAN STRATEGI BERTAHAN HIDUP KELUARGA BURUH PABRIK UNTUK MEMENUHI KEBUTUHAN HIDUP \\ KELUARGA (Studi Kasus di Pabrik Karet PTPN XII Kebun Mumbul Kecamatan Mumbulsari Kabupaten Jember)
}

Gender Role and Survival Strategy of Factory Worker's Families to Meet Their Family Needs Case Study at PTPN XII Mumbul Garden, Mumbulsari District, Jember District (Case Study at PTPN XII Kebun Mumbul Kecamatan Rubber Factory Mumbulsari, Jember Regency)

\author{
Annisa Trya Puspitasari ${ }^{1}$, Diah Puspaningrum ${ }^{1}$ \\ ${ }^{1}$ Program Studi Agribisnis, Fakultas Pertanian Universitas Jember \\ Email : annisatryapuspitasari@gmail.com
}

\begin{abstract}
PTPN XII Kebun Mumbul rubber factory workers have male and female workers who have differences. These differences will form a role that can be seen from the activity. The relatively low labor income makes the family of rubber factory workers carry out a survival strategy. This study aims to determine; the role of gender and survival strategies of rubber factory workers' families in PTPN XII Kebun Mumbul. Determination of the research area using a purposive method, namely PTPN XII Kebun Mumbul Rubber Factory. The method of determining informants is carried out deliberately using certain considerations. Data collection methods include interviews, observation and document study. The data is then analyzed using Gender Framework Analysis (GFA) and Miles and Huberman analysis. The results showed that 1) The role of husband and wife in the rubber factory worker family there are productive, reproductive and social roles. In the emic view is a wife who is used to working, gender issues that exist in the rubber factory workers' families that is heavier workload. (2) Survival strategies carried out by rubber factory workers' families, namely; alternative self-help subsystem, frugality that is saving and minimizing expenditure, network strategy by utilizing social networks in the surrounding environment.
\end{abstract}

Keywords: Gender, Roles, Survival Strategies, Self-Help Alternative Subsystems, Frugality, Network Strategy

\section{ABSTRAK}

Buruh pabrik karet PTPN XII Kebun Mumbul terdapat buruh laki-laki dan buruh wanita yang memiliki perbedaan. Perbedaan tersebut akan membentuk suatu peran yang dapat terlihat dari aktivitas. Pendapatan buruh yang relatif rendah membuat keluarga buruh pabrik karet melakukan strategi bertahan hidup. Penelitian ini bertujuan untuk mengetahui; peran gender dan strategi bertahan hidup keluarga buruh pabrik karet di PTPN XII Kebun Mumbul. Penentuan daerah penelitian menggunakan purposive method yaitu pada Pabrik Karet PTPN XII Kebun Mumbul. Metode penentuan informan dilakukan secara sengaja menggunakan pertimbangan tertentu. Metode pengumpulan data berupa wawancara, observasi dan studi dokumen. Data tersebut kemudian dianalisis menggunakan analisis Gender Framework Analysis (GFA) dan 
Miles and Huberman. Hasil penelitian menunjukkan bahwa 1) Peran suami dan istri pada keluarga buruh pabrik karet terdapat peran produktif, reproduktif dan sosial. Pada pandangan emik adalah suatu yang sudah biasa istri turut bekerja, isu gender yang ada pada keluarga buruh pabrik karet yaitu beban kerja lebih berat. (2) Strategi bertahan hidup yang dilakukan oleh keluarga buruh pabrik karet yaitu; alternatif subsistem swadaya, berhemat yaitu menabung dan meminimalisir pengeluaran, strategi jaringan dengan memanfaatkan jaringan sosial di lingkungan sekitar

Kata Kunci : Gender, Peran, Strategi Bertahan Hidup, Alternatif Subsistem Swadaya, Berhemat, Strategi Jaringan.

\section{PENDAHULUAN}

PTPN XII merupakan wadah yang berperan dalam usaha pengembangan produk perkebunan. Salah satu produk unggulan PTPN XII yaitu tanaman karet. Perkebunan yang membudidayakan tanaman karet salah satunya yaitu PTPN XII Kebun Mumbul. PTPN XII Kebun Mumbul merupakan salah satu perkebunan budidaya karet yang memproduksi getah karet (lateks) menjadi sheet RSS (Ribbed Smoke Sheet) dan TBC (Thin Brown Crepe). Kegiatan usaha yang ada di PTPN XII Kebun Mumbul di antaranya meliputi pengembangan usaha di bidang perkebunan, agrowisata, agribisnis dan industri hilir lainnya. PTPN XII Kebun Mumbul terletak di Desa Mumbulsari yang menunjukkan bahwa desa ini memiliki potensi besar untuk tanaman karet. Potensi yang besar ini baik untuk pertumbuhan ekonomi, namun penduduk Desa Mumbulsari tidak dapat memanfaatkannya, mereka hanya dapat bertindak sebagai penggarap atau buruh.

Menurut (Nurachmad, 2009) buruh merupakan setiap orang yang bekerja pada perusahaan dan lahan yang menyumbangkan tenaga kerjanya demi kelangsungan hidupnya, dimana buruh tersebut tidak memiliki sarana ataupun faktor produksi selain tenaganya sendiri. Buruh dibedakan menjadi beberapa buruh menurut cara pengupahannya yakni buruh tetap, buruh harian dan buruh borongan. Bagi buruh yang jumlah anggota keluarganya cukup besar dengan pendapatan yang diterima relatif rendah menjadikan buruh harus bekerja lebih keras agar memperoleh tambahan untuk memenuhi kebutuhan sehari-hari anggota keluarga yang ditanggungnya.

Buruh di pabrik karet PTPN XII Kebun Mumbul terdapat buruh laki-laki dan juga buruh wanita. Buruh laki-laki yang bekerja di pabrik merupakan pekerjaan utama mereka untuk menafkahi keluarga, sedangkan pada buruh wanita yang bekerja di pabrik karet merupakan pekerjaan yang dilakukan untuk menambah penghasilan keluarga. Untuk membantu ekonomi keluarga, peran wanita yang bekerja sangat dibutuhkan terutama dalam hal membantu menambah penghasilan keluarga. Sistem pendapatan buruh pabrik karet adalah berdasarkan jenis kegiatan. Setiap kegiatan yang ada di pabrik memiliki pendapatan yang berbeda. Pendapatan akan di diberikan berdasarkan jumlah produksi dari masing-masing kegiatan lalu dibagi dengan jumlah buruh dan dikalikan dengan jumlah masuk kerja. Kegiatan pengolahan memiliki target produksi sebesar 412/kg, kegiatan sortasi sebesar 150/kg dan kegiatan pengepakan sebesar $84 / \mathrm{kg}$ dengan jumlah $1 \mathrm{~kg}$ yang telah ditetapkan oleh pabrik adalah $3.500 / \mathrm{kg}$.

Pekerjaan di pabrik karet PTPN XII Kebun Mumbul merupakan aktivitas ekonomi masyarakat di sekitar lingkungan pabrik karet. Proses pengelolaan dalam pabrik karet terdapat beberapa kegiatan pekerjaan yang dikerjakan oleh buruh laki-laki dan juga buruh wanita. Kegiatan pekerjaan tersebut dimulai dari tahap pengolahan, pengasapan, sortasi hingga pengepakan. Proses produksi pengolahan karet membutuhkan peran gender dalam pabrik karet. Buruh laki-laki dan buruh wanita memiliki perbedaan secara alami dan perbedaan yang di karenakan pengaruh pada lingkungan di dalam masyarakat akan terbentuk suatu peran yang berbeda antara buruh laki-laki dan buruh wanita. Perbedaan peran tersebut dapat terlihat dari 
aktivitas yang dikerjakan oleh buruh laki-laki beserta istrinya dan buruh wanita beserta suaminya. Aktivitas yang akan dilihat adalah pada 3 kegiatan yaitu kegiatan produktif, reproduktif dan sosial. Suatu peran dapat dilihat dari pembagian kerja yang terbagi dalam 3 kegiatan yaitu kegiatan produktif, reprodukti dan sosial (Putri, 2010).

Buruh laki-laki dan buruh wanita yang bekerja di pabrik karet selain terdapat pembagian peran, pendapatan yang relatif rendah membuat mereka bekerja untuk memenuhi kebutuhan hidup sehari-hari keluarganya seperti sandang, pangan dan papan. Peranan laki-laki bekerja dalam rangka sebagai kepala keluarga yang harus menafkahi keluarganya, dan peran penting wanita bekerja dalam rangka untuk menunjang pendapatan keluarga atau perekonomian keluarga. Buruh wanita pabrik karet tidak hanya memegang tanggung jawab sebagai seorang ibu rumah tangga, namun juga sebagai tenaga kerja bagi maupun perusahaan perkebunan. Selain itu, mereka juga harus bertanggung jawab dalam mengatur perekonomian keluarga seperti pendapatan dan pengeluaran rumah tangga.

Pada penelitian (Tarina, 2014) bahwa buruh outsourcing menerapkan mekanisme survival dengan beberapa strategi, yang pertama adalah mereka memilih bertahan dengan cara menerapkan pola hidup hemat. Buruh outsourcing tidak mengurangi jatah makan namun buruh outsourcing berupaya mengatur pola makan mereka sehingga jatah pengeluaran untuk makan tidak membengkak. Mekanisme survive kedua adalah dengan menggunakan alternatif subsistem yaitu swadaya, dengan memiliki pekerjaan sampingan yang dilakukan di luar aktivitas kerjanya sehari-hari yaitu sebagai buruh outsourcing dan sebagian dari istri buruh outsourcing ikut bekerja membantu suaminya dalam mencukupi perekonomian keluarga. Upaya lain yang dilakukan oleh buruh outsourcing adalah dengan berhutang atau meminjam uang.

Strategi bertahan hidup adalah salah satu upaya yang dapat dilakukan oleh seseorang atau kelompok terutama pada masyarakat pedesaan atau penduduk lokal ketika menghadapi permasalahan hidup dalam upaya meningkatkan perekonomian untuk memenuhi segala kebutuhan hidup, termasuk buruh pabrik karet yang harus bertahan hidup dengan pendapatan yang relatif rendah. Berbagai cara dilakukan oleh keluarga buruh pabrik karet untuk memenuhi kebutuhan hidup. Keluarga buruh wanita pabrik karet mengikutsertakan peran anggota keluarga dalam kegiatan produktif guna menambah penghasilan keluarga.

Beberapa penelitian telah mengkaji tentang peran gender dan juga strategi bertahan hidup, namun masing-masing daerah tentu memiliki karakteristik tersendiri terkait tema tersebut. Penelitian yang dilakukan oleh (Putri, 2010) yang berjudul "Relasi Gender pada Rumah Tangga Petani Sayuran Dataran Rendah" meneliti tentang pembagian kerja petani sayur dalam 3 kegiatan yaitu kegiatan produktif, reproduktif dan sosial. Temuan dari penelitian yakni curahan waktu terbanyak dihabiskan oleh istri dalam kegiatan produktif, reproduktif dan sosial. Penelitian yang dilakukan oleh (Chiari, 2015) yang berjudul "Strategi Bertahan Hidup Petani saat Musim Kemarau" menunjukkan hasil strategi bertahan hidup petani sayur yang tidak melakukan aktivitas pertanian di musim kemarau adalah dengan cara menerapkan strategi penghematan, wirausaha dan jasa, berhutang serta pemanfaatan lembaga. Sedangkan dalam penelitian ini lebih memfokuskan pada karakteristik buruh pabrik yang bekerja pada orang lain, dengan fakta bahwa upah yang didapat minimum dan tidak sebanding dengan tenaga yang dicurahkan. Sehingga peneliti menggabungkan masalah peran gender pada buruh pabrik dengan strategi bertahan hidup yang dilakukan oleh buruh pabrik. Sebagaimana yang diketahui bahwa penelitian tentang peran gender dan strategi bertahan hidup buruh pabrik masih minim dibandingkan dengan penelitian tentang peran gender dan strategi bertahan hidup petani, nelayan dan lain sebagainya. Penelitian ini perlu dilakukan dengan tujuan untuk memberikan strategi bertahan hidup bagi keluarga buruh pabrik karet sehingga ketahanan hidup buruh pabrik karet di PTPN XII Kebun Mumbul Kecamatan Mumbulsari Kabupaten Jember dapat tercapai.

Berdasarkan permasalahan yang ada tersebut dapat dirumuskan beberapa rumusan masalah yaitu: (1) Bagaimana peran gender yang terdapat dalam keluarga buruh pabrik karet di PTPN XII Kebun Mumbul Kecamatan Mumbulsari Kabupaten Jember; (2) Bagaimana strategi bertahan hidup keluarga buruh pabrk karet di PTPN XII Kebun Mumbul Kecamatan Mumbulsari Kabupaten Jember. Penelitian ini bertujuan untuk mengetahui: (1) peran gender 
yang terdapat dalam keluarga buruh pabrik karet di PTPN XII Kebun Mumbul Kecamatan Mumbulsari Kabupaten Jember; (2) strategi bertahan hidup yang dilakukan oleh keluarga buruh pabrik karet.

\section{METODOLOGI PENELITIAN}

Lokasi penelitian dilakukan di Pabrik Karet PTPN XII Kebun Mumbul Kecamatan Mumbulsari Kabupaten Jember. Menurut (Sugiyono, 2015) metode purposive merupakan suatu penentuan lokasi secara sengaja dan terencana atas pertimbangan-pertimbangan tertentu. Lokasi yang dipilih sebagai obyek penelitian adalah karena Desa Mumbulsari dekat dengan kota dimana biaya hidupnya tinggi, sedangkan pendapatan buruh pabrik karet relatif rendah dengan biaya kebutuhan keluarga yang besar. Waktu penelitian yang dilakukan yaitu dimulai pada bulan Mei 2019 hingga akhir Juli 2019.

Metode yang digunakan adalah metode deskriptif kualitatif dengan pendekatan studi kasus. Menurut (Moleong, 2014) metode deskriptif kualitatif merupakan metode penelitian yang datanya berupa kata, kalimat, skema dan gambar dimana data berbentuk deskriptif dan menggunakan analisis dalam pemecahan masalahnya. Menurut (Yin, 1997) studi kasus adalah inkuiri empiris yang menyelediki fenomena di dalam konteks kehidupan nyata, bilamana batasbatas antara fenomena dan konteks tidak tampak secara tegas atau jelas dan menggunakan berbagai sumber atau multi sumber bukti dimanfaatkan. Metode penelitian ini dipilih bertujuan untuk mendeskripsikan atau menggambarkan secara rinci mengenai peran gender dan strategi yang digunakan oleh keluarga buruh pabrik karet dalam bertahan hidup di PTPN XII Kebun Mumbul Kecamatan Mumbulsari Kabupaten Jember.

Metode yang digunakan dalam penentuan informan adalah purposive sampling yaitu teknik pengambilan sampel secara sengaja dengan pertimbangan tertentu. Menurut (Sugiyono, 2015), metode secara sengaja atau purposive sampling merupakan metode yang menggunakan teknik penentuan sampel dengan pertimbangan tertentu yang ditentukan berdasarkan kriteria yang dipilih peneliti sebagai sumber informasi karena peneliti menganggap bahwa yang dipilih tersebut memiliki informasi yang diperlukan, Informan dalam penelitian ini dibedakan menjadi dua, yaitu informan dan informan pendukung. Informan dalam penelitian ini adalah empat keluarga buruh laki-laki dan empat keluarga buruh wanita. Sedangkan informan pendukung dalam penelitian ini adalah mandor.

Metode pengumpulan data digunakan untuk memudahkan peneliti dalam mendapatkan data yang akurat dan terpercaya (Sugiyono, 2015). Metode pengumpulan data yang digunakan pada penelitian ini adalah wawancara, observasi dan dokumentasi. Wawancara dilakukan untuk mendapatkan data yang terkait dengan peran gender dan strategi yang dilakukan keluarga buruh pabrik karet. observasi lapang yang dilakukan peneliti adalah dengan mengamati secara langsung kegiatan yang ada di lokasi penelitian tanpa ikut terlibat dalam suatu kegiatan aktifitas dan strategi bertahan hidup Data yang di observasi berupa gambaran sikap, kelakukan prilaku, dan tindakan keseluruhan interaksi yang berkaitan dengan peran gender dan strategi bertahan hidup. Dokumen yang dikumpulkan oleh peneliti adalah dokumentasi kegiatan, profil lokasi penelitian, jumlah buruh pabrik karet dan data-data umum lainnya yang berkaitan dengan lokasi penelitian.

Untuk menjawab rumusan masalah yang pertama mengenai peran gender adalah menggunakan analisis Gender Framework Analysis (GFA) atau analisis Harvard yaitu suatu analisis yang digunakan untuk melihat suatu profil gender dari suatu kelompok sosial dan peran gender dalam proyek pembangunan, yang terdiri tiga komponen dan interelasi yaitu: profil aktivitas, profil akses dan profil kontrol (Handayani, 2006). Profil aktivitas berdasarkan pada pembagian kerja gender siapa mengerjakan apa di dalam rumah tangga dan masyarakat, yang memuat daftar tugas perempuan dan laki-laki. Aktivitas dikelompokkan menjadi tiga yaitu: produktif, reproduktif dan sosial. Permasalahan kedua dalam penelitian adalah mengenai strategi bertahan hidup keluarga buruh pabrik karet dapat dijawab dan dijelaskan menggunakan teori strategi bertahan hidup. Teori ini digunakan untuk mengetahui strategi yang dilakukan oleh keluarga buruh pabrik karet untuk memenuhi kebutuhan hidup keluarga. Untuk menyelesaikan 
kedua permasalahan diatas dapat dianalisis menggunaka metode analisis data Miles and Huberman. Analisis data dalam penelitian ini dilakukan pada saat pengumpulan data berlangsung. Menurut (Pawito, 2007), metode ini merupakan salah satu metode yang umum digunakan pada penelitian dengan pendekatan kualitatif. Tahapan yang terdapat pada analisis Miles dan Huberman adalah pengumpulan data, reduksi data, penyajian data dan penarikan kesimpulan.

\section{HASIL DAN PEMBAHASAN}

\section{Peran Buruh Pabrik Karet di PTPN XII Kebun Mumbul}

Berdasarkan Tabel 1 keluarga buruh pabrik karet di PTPN XII Kebun Mumbul terdapat kegiatan produksi, reproduksi dan sosial. Kegiatan produksi pada keluarga buruh pabrik karet adalah pengolahan karet, sortasi karet dan pengepakan karetKegiatan reproduktif rumah tangga buruh pabrik karet di PTPN XII Kebun Mumbul mencakup: memasak, mencuci, belanja, membersihkan rumah dan mengasuh anak. Sedangkan kegiatan sosial dalam rumah tangga buruh pabrik karet di PTPN XII Kebun Mumbul adalah sebagai berikut: pengajian, arisan dan hajatan.

Tabel 1. Profil Aktifitas pada Keluarga Buruh Wanita Pabrik Karet di PTPN XII Kebun Mumbul

\begin{tabular}{|c|c|c|c|c|c|}
\hline \multirow{2}{*}{ No } & \multirow{2}{*}{ Aktivitas } & \multicolumn{2}{|c|}{ Buruh Laki-Laki } & \multicolumn{2}{|c|}{ Buruh Wanita } \\
\hline & & Suami & Istri & Suami & Istri \\
\hline \multirow[t]{4}{*}{1.} & Produktif & & & & \\
\hline & Pengolahan Karet & $\sqrt{ } \sqrt{ }$ & & & $\sqrt{ } \sqrt{ }$ \\
\hline & Sortasi Karet & & & & $\sqrt{ } \sqrt{ }$ \\
\hline & Pengepakan Karet & $\sqrt{ } \sqrt{ }$ & & & \\
\hline \multirow[t]{6}{*}{2.} & Reproduktif & & & & \\
\hline & Memasak & & $\sqrt{ } \sqrt{ }$ & & $\sqrt{ } \sqrt{ }$ \\
\hline & Mencuci & & $\sqrt{ } \sqrt{ }$ & & $\sqrt{ } \sqrt{ }$ \\
\hline & Belanja & & $\sqrt{ } \sqrt{ }$ & & $\sqrt{ } \sqrt{ }$ \\
\hline & Membersihkan Rumah & & $\sqrt{ } \sqrt{ }$ & $\sqrt{ }$ & $\sqrt{ } \sqrt{ }$ \\
\hline & Mengasuh Anak & & $\sqrt{ } \sqrt{ }$ & $\sqrt{ }$ & $\sqrt{ } \sqrt{ }$ \\
\hline \multirow[t]{4}{*}{3.} & Sosial & & & & \\
\hline & Pengajian & $\sqrt{ }$ & $\sqrt{ } \sqrt{ }$ & $\sqrt{ }$ & $\sqrt{ } \sqrt{ }$ \\
\hline & Arisan & & & & $\sqrt{ } \sqrt{ }$ \\
\hline & Hajatan & $\sqrt{ } \sqrt{ }$ & $\sqrt{ } \sqrt{ }$ & $\sqrt{ } \sqrt{ }$ & $\sqrt{ } \sqrt{ }$ \\
\hline $\begin{array}{l}\sqrt{ } \\
\sqrt{ }\end{array}$ & $\begin{array}{l}\text { : pelaku } \\
\text { : pelaku dominan }\end{array}$ & & & & \\
\hline
\end{tabular}

\section{Peran Produktif Keluarga Buruh Pabrik Karet di PTPN XII Kebun Mumbul}

a. Pengolahan Karet

Aktivitas produksi pada keluarga buruh pabrik karet yang pertama adalah pengolahan karet. Pengolahan karet dilakukan di pabrik karet PTPN XII Kebun Mumbul yang dilakukan oleh suami dari keluarga buruh laki-laki dan istri dari keluarga buruh wanita. Buruh yang bekerja sebagai buruh pabrik dibagian pengolahan karet memulai pekerjaan dari jam 6 pagi hingga sore, diawali dengan rol yang di ikuti oleh seluruh staff dan juga buruh pabrik karet.

Lateks yang baru datang tidak langsung di olah, tetapi dilakukan pengecekan terlebih dahulu. Lateks yang bersih adalah lateks stabil dengan berwarna putih dan tidak terdapat gumpalan itulah yang akan diolah. Lateks stabil akan di masukkan di bak yang akan ditambahkan dengan air dan asam semut untuk dibekukan beberapa jam. Proses pembekuan selesai akan dilakukan proses penggilingan sebelum dimasukkan ke ruang pengasapan dan di sortasi dan disinilah lateks berubah menjadi sheet karet. 
Proses penggilingan, dimana sebelum menuju ke mesin penggilingan lembaran di angkat ke saluran air yang berguna untuk merendam lembaran agar tidak lengket dan membersihkan sisa serum asam semut, serum dan kotoran pada saat proses pembekuan. Penggunaan air tersebut sangat diperhatikan dalam proses penggilingan yang bertujuan untuk melancarkan jalannya lembaran menuju mesin penggilingan dan mengurangi terjadinya cacat giling pada proses penggilingan.

b. Sortasi Karet

Lateks yang sudah diolah akan dikeringkan di ruang pengasapan, lalu setelah kering akan dibawa ke ruang sortasi dan akan menjadi sheet. Proses sortasi ini sama halnya dengan proses pengolahan, yaitu dengan melakukan perbedaan mutu terlebih dahulu. Mutu sheet karet yang ada di Pabrik Karet Kebun Mumbul ada empat, yaitu RSS 1, RSS 2, RSS 3 dan cutting, dimana pada setiap mutu ini memiliki ciri-ciri tersendiri.

Sheet terbagi menjadi 4 mutu, yaitu RSS 1, RSS 2, RSS 3 dan cutting. RSS 1 memiliki ciri-ciri kekar, bersih, kering, bebas cendawan atau jamur, tidak terdapat gelembung dan tidak cacat. RSS 2 memiliki ciri-ciri yang sama seperti RSS 1 hanya saja terdapat gelembung dengan persentase sebesar 5\% dan untuk RSS 3 memiliki gelembung dan jamur atau cendawan dengan persentase sebesar $10 \%$. Mutu yang terakhir adalah cutting memiliki ciri-ciri sheet yang terlalu kering sehingga warnanya hitam atau sheet yang masih mentah sehingga harus dipotong c. Pengepakan Karet

Pengepakan karet dilakukan setelah proses sortasi dengan tujuan agar barang produksi tidak terkontaminasi oleh benda asing dan menyiapkan barang atau produk yang siap kirim. Pengepakan pada produk karet dilakukan dari pengepressan hingga pengemasan dan pelaburan. Kemasan dan pelaburan tersebut berfungsi menghindari antar bale saling menempel dan meminimalisir tumbuhnya cendawan pada sheet.

Pengepakan pada bale terdapat 2 ukuran, yaitu small bale dan big bale. Sebelum dilakukan tahap pengepresan, tiap bale akan ditimbang terlebih dahulu sesuai berat yang sudah ditentukan oleh pabrik, lalu dilakukan pemasangan begel pada kemasan big bale. Pemasangan begel tersebut akan didiamkan selama 24 jam agar hasil pengepresan tidak mengembang. Setelah begel dibuka, maka aka dilakukan pengemasan dan pelaburan.

Pengemasan small bale dan big bale memiliki tahap yang berbeda, pengemasans small bale hanya menggunakan plastik saja dan dipress sebanyak 2 kali dengan menumpukkan press yang pertama sesuai berat yang sudah ditentukan, lalu dipress lagi sebanyak 3 kemasan small bale sekaligus pada mesin yang berbeda yaitu mesin hydrolis. Pada kemasan big bale pengpressan hanya dilakukan sekali kemudian dipasang begel untuk mengunci pengepresan selama 24 jam lalu dikemas menggunakan lembaran karet dan dilakukan pelaburan agar bale tidak saling menempel pada saat proses pengiriman dan terhindar dari tumbuhnya jamur dan cendawan.

\section{Peran Reproduktif Keluarga Buruh Pabrik Karet di PTPN XII Kebun Mumbul \\ a. Memasak}

Memasak merupakan salah satu kegiatan reproduktif yang penting dalam rumah tangga, karena memasak merupakan suatu kegiatan yang menyediakan makanan untuk keluarga. Dalam rumah tangga buruh pabrik karet, memasak merupakan tugas dari seorang istri. Istri akan bangun lebih awal untuk mulai memasak hidangan. Istri memasak sendirian tanpa di bantu oleh suami dimana istri akan bangun lebih awal untuk menyiapkan sarapan. Terkadang istri juga membawa dan menyiapkan bekal makanan untuk dimakan ketika istirahat siang di pabrik. Setelah pulang dari bekerja, para istri akan memasak lagi untuk makan malam.

b. Mencuci

Salah satu kegiatan lainnya dalam rumah tangga adalah mencuci, yang dimaksud mencuci dalam hal ini adalah mencuci pakaian yang telah digunakan sehari-hari. Mencuci adalah kegiatan yang dilakukan oleh istri dalam rumah tangga keluarga buruh pabrik karet di PTPN XII Kebun Mumbul. 
Istri mencuci pakaian yang digunakan sehari-hari pada waktu pagi sebelum berangkat ke pabrik dan ada yang dilakukan pada saat sudah selesai mengurus anak. Tergantung bagaimana istri membagi waktunya.

c. Belanja

Keluarga mendapatkan bahan makanan ketika sesorang berbelanja kebutuhan pokok baik lauk pauk maupun sayur. Belanja kebutuhan sehari-hari dalam rumah tangga buruh pabrik karet yang ada di PTPN XII Kebun Mumbul dilakukan oleh seorang istri. Pengelola keuangan juga diserahkan ke istri untuk belanja. Istri akan belanja kebutuhan keluarga seperti bahan makanan setiap harinya.

d. Membersihkan Rumah

Rumah merupakan tempat tinggal bersama dengan keluarga yang selalu memberikan kenyamanan dan senantiasa dijaga kebersihannya. Membersihkan rumah dalam rumah tangga buruh pabrik karet dilakukan oleh istri. Meskipun istri juga bekerja, namun istri tetap menjalankan perannya sebagai ibu rumah tangga. Istri membersihkan rumah ketika pulang kerja jika tidak sempat membersihkan sebelum berangkat. Kegiatan membersihkan dilakukan oleh istri. Meskipun istri sudah bekerja, namun istri tetap melakukan kegiatan sebagai seorang ibu rumah tangga.

e. Mengasuh Anak

Mengasuh anak merupakan hal yang dilakukan dengan menjaga anak maupun mengawasi anaknya. Buruh pabrik karet di PTPN XII Kebun Mumbul yang menjadi informan dalam penelitian ini memiliki anak yang usianya masih bersekolah dan masih balita. Ada yang masih berumur 3-4 tahun, ada yang masih sekolah TK, SD, dan juga SMK. Di usia seperti itu, anak masih dalam pengawasan orang tua dan masih menjadi tanggungan orang tua.

Mengasuh anak merupakan tugas bersama dalam keluarga, karena anak adalah milik suami dan istri yang harus dijaga bersama-sama. Anak yang belum menikah juga masih menjadi tanggung jawab orang tua. Kegiatan mengasuh anak dalam keluarga buruh wanita pabrik karet dilakukan oleh istri dengan mengantar anak sekolah, mengantar ngaji. Suami turut membantu apabila istri lembur di pabrik.

\section{Peran Sosial Keluarga Buruh Pabrik Karet di Pabrik Karet PTPN XII Kebun Mumbul}

a. Pengajian

Pengajian merupakan salah satu kegiatan keagamaan yang biasa dilakukan bersama masyarakat sekitar. Pengajian rutin biasanya dilakukan seminggu sekali. Pengajian yang diadakan di sekitar rumah keluarga buruh pabrik karet ada pengajian untuk bapak-bapak dan ada pengajian untuk ibu-ibu. Suami dan istri mendapat kesempatan yang sama untuk mengikuti pengajian yaitu kegiatan keagamaan. Pengajian tersebut diadakan setiap malam jumat manis dan seminggu sekali serta bertempatan di lingkungan sekitar tempat tingggal mereka.

b. Arisan

Arisan merupakan salah satu kegiatan sosial yang biasa dilakukan pada wanita. Kegiatan ini rata-rata dilakukan setiap sebulan sekali. Buruh wanita pabrik karet mengikuti kegitan arisan di tempat kerjanya yaitu di pabrik karet PTPN XII Kebun Mumbul yang di adakan oleh mandornya. Kegiatan arisan dilakukan oleh istri. Mereka mengikuti kegiatan arisan yang diadakan oleh mandornya di pabrik karet PTPN XII Kebun Mumbul. Kegiatan arisan tersebut dilakukan setiap buruh wanita pabrik karet menerima gajinya.

c. Hajatan

Hajatan merupakan perayaan atau syukuran terhadap suatu acara yang terjadi seperti pernikahan dan sunatan. Sudah menjadi tradisi di lingkungan tempat tinggal buruh prabik karet terdapat kegiatan hajatan, baik buruh pabrik karet yang mempunyai acara hajatan ataupun tetangganya. Terkada istri membantu acara tersebut. Istri turut membantu dan suami juga datang saat tetangga mengadakan acara hajatan. Baik buruh pabrik ataupun tetangga yang mempunyai acara hajatan, mereka saling membantu karena sudah menjadi tradisi di lingkungan sekitar. 


\section{Perspektif Emik Peran Gender Buruh Pabrik Karet di PTPN XII Kebun Mumbul}

Tabel 2. Perspektif Emik dan Isu Gender Buruh Pabrik Karet

\begin{tabular}{lc}
\hline \multicolumn{1}{c}{ Perspektif Emik } & \multicolumn{1}{c}{ Isu gender } \\
\hline Budaya Patriarki & \\
Keikutsertaan & Beban Ganda / Beban kerja lebih berat \\
Tidak Ada Paksaan &
\end{tabular}

Sumber: Data Primer Tahun 2019

Perspektif emik pada peran gender buruh pabrik berdasarkan teori struktural fungsional. Menurut (Fakih, 1996), struktural fungsionalisme menganut bahwa kondisi yang adalah normal dan sehat sehingga tidak diperlukan perubahan. Posisi laki-laki dan wanita secara terus menerus mencapai keseimbanagn dan harmoni. Perspektif emik dalam penelitian ini berdasarkan budaya patriarki, keikutsertaan istri bekerja dan tidak ada paksaan.

a. Budaya Patriarki

Kegiatan rumah tangga buruh pabrik karet di PTPN XII Kebun Mumbul dilakukan oleh suami dan istri, kegiatan produktif didominasi oleh suami dan istri dan kegiatan reproduktif dan sosial didominasi oleh istri. Menurut mereka ini adalah hal wajar yang sudah biasa ada di kebudayaan lingkungan mereka dimana seorang suami bertugas untuk bekerja dan istri bertugas untuk mengurus pekerjaan rumah. Kebudayaan mereka masih menganut buadaya patriarki yang kuat karena beranggapan bahwa istri yang mengurus rumah dan suami bekerja. Desa Mumbulsari mayoritasnya adalah etnis Madura, sehingga budaya patriarki mereka juga cukup melekat.(Mosse, 1996) mengatakan, patriarki sebutan yang digunakan untuk menggambarkan dominasi laki-laki atas wanita dan anak-anak dalam keluarga yang berlanjut kepada dominasi laki-laki dalam semua lingkup masyarakat lainnya.

b. Keikutsertaan

Disamping mengerjakan kegiatan reproduktif, istri juga turut mengerjakan kegiatan reproduktif dengan turut bekerja untuk membantu perekonomian keluarga. Istri melakukan itu karena memang menyadari bahwa perekonomian mereka masih belum cukup sehingga mereka berinisiatif untuk membantu suami. Pendapatan suami yang masih belum cukup tersebut membuat istri tidak lantas diam saja di rumah. Bantuan istri dengan turut bekerja agar dapat membantu keluarga untuk menutupi kebutuhan hidup yang masih belum tercukupi. Kurangnya biaya membuat istri untuk membantu suaminya dengan ikut bekerja, dengan hasil yang didapat digunakan untuk menambah biaya keperluan keluarga. Keikutsertaan istri membantu suami ini merupakan tindakan biasa dilakukan istri . mereka ikhlas membantu suaminya tanpa ada paksaan dan ini merupakan kesadaran dari istri untuk membantu suaminya dalam memperbaiki ekonomi keluarga mereka.

c. Tidak ada Paksaan

Pembagian kerja tersebut adalah suatu yang sudah biasa dan lumrah terjadi disana. Meskipun istri juga bekerja untuk menambah penghasilan, namun mereka tak melupakan perannya sebagai seorang istri yang juga harus melakukan kegiatan rumah tangga seperti mencuci, memasak, belanja, mengasuh anak dan membersihkan rumah, kegiatan reproduktif tersebut dilakukan semua oleh istri. Kadangkala suami mereka turut serta membantu. Istri mengeluarkan banyak waktu dan tenaga melakukan tiga kegiatan sekaligus baik kegiatan produktif, reproduktif dan sosial, namun hal itu tak membuat istri merasa terbebani. Melakukan kegiatan reproduktif yang mereka kerjakan sendirian, menurut mereka kegiatan tersebut memang sesuatu yang harus mereka lakukan ketika sudah berkeluarga.

Isu gender dalam keluarga buruh pabrik karet di PTPN XII Kebun Mumbul adalah beban ganda atau beban kerja lebih berat. Berdasarkan analisis gender yang berupa profil pembagian kerja dalam keluarga buruh pabrik karet di PTPN XII Kebun Mumbul menunjukkan bahwa adanya isu beban ganda atau beban kerja lebih berat. Beban ganda menurut (Handayani, 
2006) wanita menerima beban ganda karena bekerja domestik, tetapi mereka masih harus bekerja mencari nafkah. Pada keluarga buruh pabrik karet, istri lebih banyak mengeluarkan waktu daripada suami. Istri tidak hanya menjalankan kegiatan reproduktif dan sosial tetapi juga membantu suami pada kegiatan produktif. Terlebih lagi ketika produksi karet meningkat, istri bekerja dari pagi hingga sore dan malam hari. Oleh karena itu isrti harus bangun pagi mulai subuh bergegas untuk masak, mencuci dan bersih-bersih kemudian berangkat kerja, sepulang bekerja istri juga harus mengurus anak, dan memasak untuk makan malam.

\section{Strategi Bertahan Hidup Keluarga Buruh Wanita Pabrik Karet di PTPN XII Kebun Mumbul Kecamatan Mumbulsari Kabupaten Jember}

Tabel 3. Pendapatan dan Pengeluaran Buruh Pabrik Karet

\begin{tabular}{|c|c|c|c|}
\hline No & Bagian Pekerjaan & $\begin{array}{c}\text { Pendapatan Rata-Rata Buruh } \\
\text { Pabrik Karet (Rp/bln) }\end{array}$ & $\begin{array}{c}\text { Total Pengeluaran Kebutuhan } \\
\text { Keluarga (Rp/bln) }\end{array}$ \\
\hline 1. & Pengolahan & $\pm \mathrm{Rp} 1.297 .782$ & \\
\hline 2. & Sortasi & $\pm \mathrm{Rp} 833.814$ & Rp 1.000.000-Rp 1.500.000 \\
\hline 3. & Pengepakan & $\pm \mathrm{Rp} 882.000$ & \\
\hline
\end{tabular}

Sumber : Data Primer 2019

Besarnya pendapatan yang diperoleh dari buruh pabrik karet tergolong rendah dengan biaya pengeluaran setiap bulan yang besar, sehingga keluarga buruh wanita pabrik karet melakukan startegi bertahan hidup untuk memenuhi kebutuhan hidupnya

Pendapatan buruh pabrik karet tidak menentu karena tergantung lateks dan produksi yang dihasilkan. Jika lateks dan produksi sedang menurun, maka saja pendapatan kurang dari yang diatas. Pendapatan buruh pabrik karet juga berbeda-beda seperti pendapatan buruh pabrik pada bagian pekerjaan pengolahan, mereka mendapatkan upah Rp 1.297.782/bln, pada bagian pekerjaan sortasi mendapatkan upah $\mathrm{Rp} 833.814$ dan pada bagian pekerjaan pengepakan mendapatkan upah Rp 882.000. Dengan pendapatan buruh pabrik tersebut tergolong pendapatan yang rendah menurut (BPS, 2016) dimana golongan pendapatan rendah adalah pendapatan ratarata kurang dari Rp 1.500.000, dimana total pengeluaran kebutuhan keluarga buruh pabrik karet lebih besar daripada pendapatan mereka sebagai buruh, dengan rata-rata pengeluaran adalah sebesar Rp 1.000.000-Rp 1.500.000.

Pendapatan buruh pabrik tersebut harus membuat mereka melakukan strategi untuk dapat memenuhi kebutuhan sehari-harinya. Meskipun suami kepala rumah tangga yang mencari nafkah, tak menutup kemungkinan bagi istri untuk ikut bekerja demi membantu perekonomian keluarga mereka. Keluarga buruh pabrik karet mengikutsertakan peran anggota keluarganya yaitu istri dengan bekerja untuk menambah penghasilan. Istri bekerja untuk membantu suami menambah perekonomian keluarga. Penghasilan suami yang bekerja tidak cukup untuk memenuhi kebutuhan keluarga, sehingga istri harus bisa mengatur, mengurusi dan bertanggung jawab atas semua kebutuhan dalam keluarga. Adanya persoalan tersebut, maka keluarga buruh pabrik karet melakukan strategi agar pemenuhan kebutuhan keluarga dapat terpenuhi. (Scott, 1981) memandang bahwa ada tiga cara yang dilakukan masyarakat miskin untuk bertahan hidup yaitu:

1. Menggunakan alternatif subsistem yaitu swadaya yang mencakup usaha kecil-kecilan, bekerja sebagai tukang atau buruh, dan melakukan migrasi untuk mencari pekerjaan

2. Mengurangi pengeluaran untuk pangan dengan cara makan hanya sekali sehari dan beralih ke makanan yang mutunya lebih rendah

3. Meminta bantuan dari jaringan sosial seperti sanak saudara, kawan-kawan sedesa, memanfaatkan hubungan dengan pelindungnya (patron) 
Penelitian Scott tersebut menjelaskan bagaimana individu atau kelompok mampu bertahan hidup pada kondisi yang sulit seperti yang dialami oleh keluarga buruh pabrik karet. keluarga buruh pabrik karet harus berusaha untuk bertahan hidup dengan berbagai cara yang dapat mereka lakukan. Strategi mempertahankan hidup yang tepat sangat penting untuk kelangsungan hidup keluarga buruh pabrik karet. Berdasarkan teori dan hasil penelitian di lapang mengenai strategi bertahan hidup yang dilakukan keluarga buruh pabrik karet sebagai berikut:

Tabel 4. Strategi Bertahan Hidup Keluarga Buruh Pabrik Karet diPTPN XII Kebun Mumbul

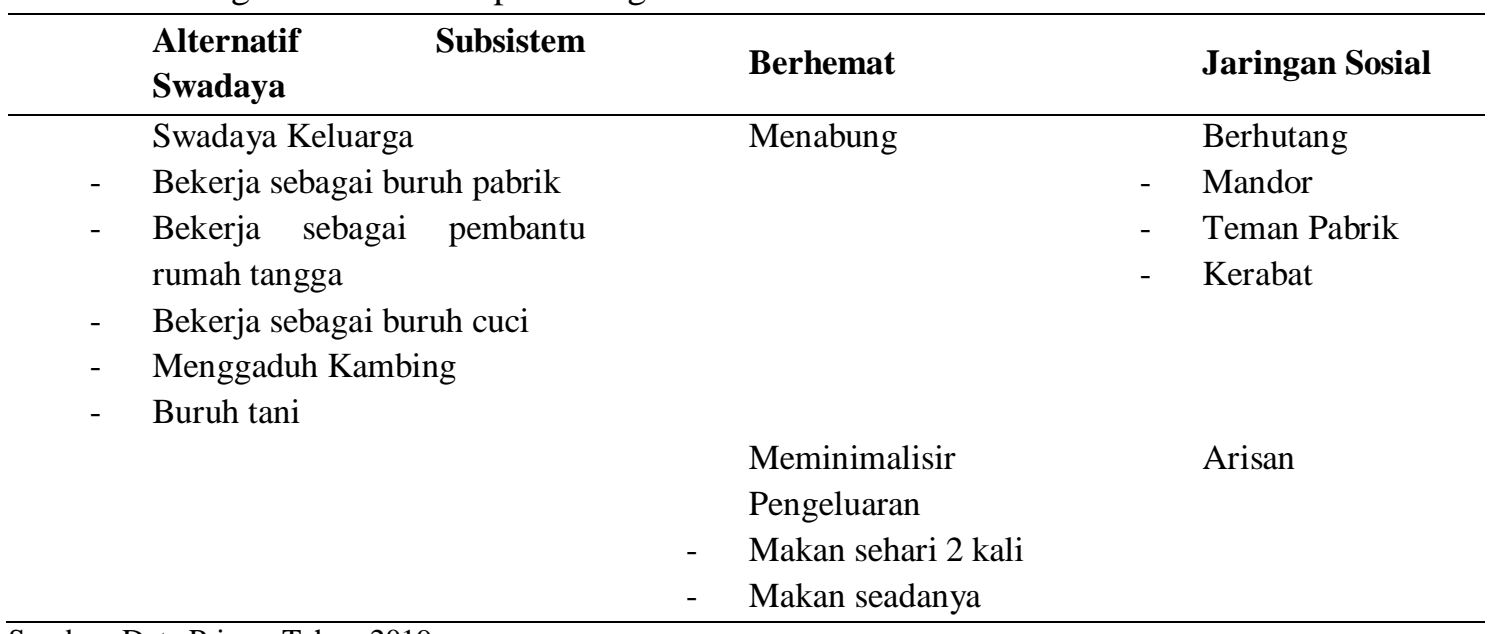

Sumber: Data Primer Tahun 2019.

\section{Strategi Bertahan Hidup Alternatif Subsistem Swadaya}

Salah satu usaha yang dilakukan oleh keluarga buruh pabrik karet sebagai kemampuan mempertahankan kelangsungan hidupnya adalah dengan alternatif subsistem swadaya. Swadaya yang dimaksud adalah tindakan yang dilakukan dengan kemampuan, usaha atau sumber yang dimiliki oleh keluarga buruh pabrik karet. Hal tersebut merupakan perluasan mata pencaharian yang dilakukan oleh keluarga buruh pabrik karet. Strategi ini dapat melibatkan seluruh sumber daya yang ada dalam keluarga buruh pabrik karet, seperti istri yang turut bekerja sebagai pencari nafkah tambahan bagi suami. Pekerjaan yang dilakukan oleh istri yaitu:

a. Bekerja sebagai buruh wanita pabrik karet.

Istri turut bekerja menjadi buruh pabrik karet memiliki alasan tersendiri. Menurut mereka, hanya dengan mengandalkan pendapatan dari suami saja tidak cukup untuk memenuhi kebutuhan keluarga. Meskipun menjadi buruh pabrik dengan bekerja seharian, istri tetap lakukan karena untuk menambah perekonomian keluarga. Istri yang bekerja sebagai buruh pabrik karet mendapatkan upah sebesar Rp 833.814/bulan pada bagian sortasi dan Rp 1.297.782/bulan pada bagian pengolahan karet. Pendapatan tersebut mereka gunakan untuk memenuhi kebuhan keluarga.

b. Bekerja sebagai Pembantu Rumah Tangga

Selain istri yang bekerja sebagai buruh wanita pabrik karet, adapun istri bekerja sebagai pembantu rumah tangga. Jam kerja pun berbeda, ada yang bekerja dari pagi hingga sore dan ada yang bekerja dari pagi hingga siang. Penghasilan yang didapat daribekerja sebagai pembantu rumah tangga adalah sebesar Rp 450.000-Rp 650.000/bulan.

c. Bekerja sebagai Buruh Cuci

Untuk membantu menambah pengahasilan suami, istri juga bekerja sebagai buruh cuci. Istri bekerja untuk mencuci pakaian orang lain dengan bekerja selama 2-3 hari dalam seminggu. Pendapatan yang didapatkan sebagai buruh cuci adalah sebesar Rp 300.000-Rp 450.000/bulan.

Strategi yang dilakukan keluarga buruh pabrik karet salah satunya yaitu dengan mengikutsertakan istri bekerja sebagai buruh pabrik, pembantu rumah tangga dan buruh cuci untuk menambah penghasilan suami dimana penghasilan tidak cukup untuk memenuhi 
kebutuhan keluarga. Adapun pekerjaan lain yang dilakukan oleh suami dari keluarga buruh pabrik karet yaitu:

d. Penyadap Karet

Penyadap karet merupakan pekerjaan yang dilakukan oleh suami dari buruh wanita pabrik karet dimana mereka akan bekerja pada malam hari untuk membuat irisan pada pohon karet yang sudah siap untuk disadap dimana nantinya akan mengeluarkan lateks dari irisan tersebut. Buruh penyadap karet kembali lagi pada pagi harinya untuk mengambil lateks yang sudah terkumpul di mangkuk dan dibawa ke pabrik untuk diolah. Pendapatan yang didapat sebagai buruh penyadap karet adalah sebesar 44 rupih per harinya. Jumlah tersebut bisa berubah tergantung dengan hasil lateks yang dikumpulan. Jika hasil lateks yang dikumpulkan sedikit, maka jumlah upah yang didapat juga akan berkurang.

e. Menggaduh kambing

Menggaduh kambing menjadi salah satu pekerjaan tambahan yang dilakukan oleh suami dari keluarga buruh wanita pabrik karet untuk menambah penghasilan. Ada yang memiliki ternak kambing sendiri dan ada pula yang merawat kambing milik orang lain. Pekerjaan menggaduh kambing ini suami lakukan pada saat pagi hingga siang hari. Suami merawat kambingnya hingga tumbuh besar lalu dijual, dan adapun yang hanya merawatnya saja dengan meberi makan kambing milik orang lain.

\section{f. Buruh Tani}

Lahan sawah yang mereka kerjakan bukanlah kepemilikan pribadi, melainkan milik orang lain. Pendapatannya pun tidak menentu dimana untuk buruh tani terkadang mereka mendapatkan 60-65 ribu Hal itu sesuai dengan penelitian (Nugraha, 2015) yang menyatakan bahwa untuk memenuhi kebutuhan hidup keluarga petani menggunakan alternatif subsistensi dengan cara sebagian istri ikut bekerja untuk membantu memenuhi kebutuhan hidupnya dan sebagian besar petani juga mempunyai pekerjaan sampingan atau pekerjaan lain selain menjadi petani.

Strategi bertahan hidup yang dilakukan dengan subsistem swadaya ini dapat dikatakan bahwa peran anggota keluarga adalah suatu tindakan untuk menambah penghasilan agar dapat memenuhi kebutuhan sehari-hari. Penghasilan yang didapat bukan hanya dari suami yang bekerja sebagai buruh pabrik maupun penyadap karet, namun juga dapat dari pekerjaan sampingan dan juga istri sebagai anggota keluarga yang turut membantu menambah penghasilan dengan cara ikut bekerja. Berdasarkan teori yang diungkapkan (Scott, 1981), maka strategi bertahan hidup alternatif subsistem swadaya dapat dijelaskan pada Gambar 1.

a. Keluarga Buruh Laki-Laki Pabrik Karet Pabrik Karet

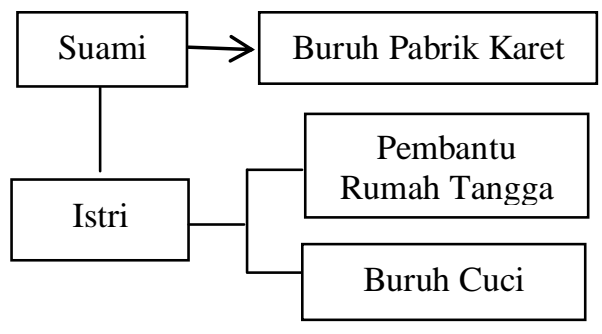

b. Keluarga Buruh Wanita Pabrik Karet

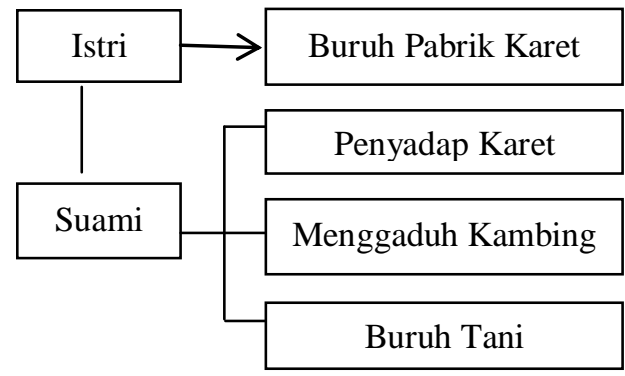

Gambar 1 Strategi Bertahan Hidup Alternatif Subsistem Swadaya

Suami yang bekerja sebagai buruh pabrik karet tidak memiliki pekerjaan lain selain menjadi buruh. Hal tersebut dikarenakan mereka sudah bekerja seharian dari pagi hingga sore sehingga tidak ada waktu lagi bagi mereka untuk mengerjakan pekerjaan yang lain. Oleh karena itu peran istri disini turut membantu suami dengan bekerja sebagai pembantu rumah tangga dan buruh cuci. Begitu juga dengan istri yang bekerja seagai buruh pabrik, dengan bekerja seharian maka suami yang memiliki pekerjaan sampingan guna menambah perekonomian keluarga dengan bekerja sebagai buruh penyadap karet, menggaduh kambing dan juga buruh tani. 


\section{Strategi Bertahan Hidup Berhemat}

Salah satu strategi yang diungkapkan oleh (Scott, 1981) adalah mengikat sabuk lebih kencang lagi yaitu dengan mengurangi jatah makan atau beralih ke makanan dengan mutu yang lebih rendah serta berhemat. Penghematan ini dilakukan guna meminimalisir pengeluaran yang berlebihan. Strategi yang biasa dilakukan oleh keluarga buruh pabrik karet adalah dengan membiasakan hidup hemat. Keluarga buruh wanita pabrik karet juga harus selektif dalam mengatur keuangan agar dapat mengatur pengeluaran keluarga dengan baik.

Penekanan atau menghemat pengeluaran merupakan strategi yang bersifat pasif yaitu dengan mengurangi pengeluaran keluarga. Dalam hal ini, keluarga buruh pabrik karet mempertahankan hidupnya dengan cara berhemat yaitu menghemat konsumsi dan memanfaatkan hasil tabungannya untuk lebaran. Strategi berhemat keluarga buruh pabrik karet adalah sebagai berikut:

a. Menghemat Pengeluaran Makan

Cara ini dilakukan karena penghasilan dari buruh pabrik karet tergolong rendah sehingga mereka harus mengatur pengeluaran agar kebutuhan mereka tetap tercukupi misalnya dengan makan seadanya dan sesekali mengurangi jatah makan menjadi sehari 2 kali jika keuangan lagi menipis. Keluarga buruh pabrik karet tetap makan 3 kali sehari, terutama keluarga yang bekerja sebagai buruh pabrik karet karena mereka harus bekerja seharian sehingga mereka membawa bekal untuk dimakan saat istirahat. Adapun kondisi keluarga buruh pabrik karet sesekali mengurangi jatah makannya dengan 2 kali sehari jika keadaan uang lagi menipis, hal tersebut dilakukan untuk menghemat pengeluaran. Hal ini sesuia dengan penelitian yang disampaikan oleh (Tarina, 2014), yang mengatakan bahwa meskipun tidak mengurangi jatah makan, namun yang dilakukan adalah dengan berupaya mengatur pola makan sehingga jata penegeluaran untuk makan tidak membengkak. Mereka pun juga makan seadanya seperti tahu dan tempe.

Selain mengurangi jatah makan keluarga buruh pabrik karet juga makan seadanya seperti makan dengan lauk tahu dan tempe. Mereka juga berhemat untuk tidak sering-sering membeli lauk dengan mutu yang lebih tinggi. Hal ini senada dengan penelitian yang disampaikan oleh (Pratiwi, 2018) yang mengatakan bahwa upaya memperkecil pengeluaran wanita mantan buruh sadap karet dengan mengurangi jatah belanja kebutuhan sehari-hari dimana yang biasanya makan dengan ayam untuk saat ini mereka harus makan dengan tempe dan tahu.

b. Menabung

Daripada membeli lauk dengan mutu yang lebih tinggi, keluarga buruh pabrik karet lebih memilih untuk menabung, keluarga buruh wanita pabrik karet menabungkan hasil pendapatannya di pabrik karet yang diadakan oleh mandor. Buruh pabrik karet menyisihkan sebagian pendapatannya untuk ditabung yang diadakan oleh mandornya, dimana terkadang mereka menabung sebesar 50 hingga 100 ribu rupiah. Hasil tabungan tersebut akan dibagikan oleh mandor kepada buruh pabrik karet menjelang lebaran. Tabungan tersebut digunakan untuk membeli pakaian baru yang akan dikenakan saat lebaran, karena mereka hanya dapat membeli pakaian baru setahun sekali yaitu saat lebaran dan juga digunakan untuk mencicil hutang.

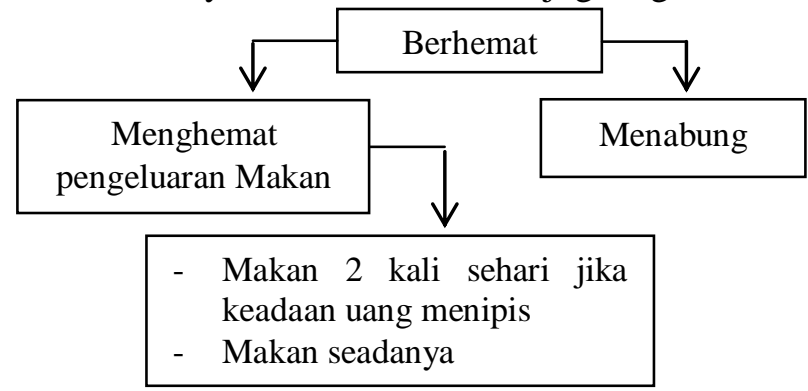

Gambar 2. Strategi Bertahan Hidup Berhemat Keluarga Buruh Pabrik 
Cara untuk berhemat keluarga buruh pabrik karet adalah dengan mengurangi jatah makan menjadi 2 kali sehari jika dalam kondisi uang menipis dengan makan seadanya seperti tahu dan tempe. Mereka juga menabung dimana tabungan tersebut akan mereka gunakan untuk kebutuhan lebaran dan mencicil hutang. Strategi bertahan hidup yang dilakukan dengan cara berhemat ini tidak lain dengan melakukan penghematan serta mengurangi sedikit pengeluaran keluarga, dengan cara mengatur dan mengelola keuangan sehingga dapat menekan pengeluaran..

\section{Strategi Bertahan Hidup Jaringan Sosial}

Menurut (Scott, 1981), Strategi jaringan dapat dilakukan dengan meminta bantuan seperti sanak saudara, kawan-kawan sedesa dan memanfaatkan hubungan dengan pelindungnya (patron). Strategi jaringan yang biasanya di lakukan keluarga buruh pabrik karet adalah dengan memanfaatkan jaringan sosial yang dimiliki yaitu dengan cara meminjam uang kepada kerabat, mandor dan memanfaatkan bantuan sosial lainnya.

Strategi jaringan sosial merupakan salah satu upaya yang dilakukan oleh keluarga buruh pabrik karet. Pemanfaatan jaringan sosial keluarga buruh pabrik karet digunakan sebagai salah satu alternatif dalam menghadapi tekanan-tekanan ekonomi. Pada saat mereka tidak memiliki sumberdaya ekonomi atau keuangan, maka mereka meminjam uang kepada kerabat atau tetangga serta ke mandor pabrik untuk dapat memenuhi kebutuhan hidup sehari-hari.

Keluarga buruh pabrik karet untuk dapat bertahan hidup mereka memanfaatkan jaringan sosial untuk mengakses sumberdaya yang tersedia di lingkungan dengan cara meminjam uang. Mereka melakukan pinjaman jika ada kebutuhan mendesak dan tidak memiliki pegangan uang. Pinjaman yang dilakukan juga untuk biaya memenuhi kebutuhan sehari-hari serta hasil pinjaman juga digunakan untuk biaya sekolah anak-anak mereka, karena biaya untuk anak mereka sokolah membutuhkan biaya yang besar apalagi setelah menginjak tahun ajaran baru. Mereka mencari pinjaman kepada kerabat, teman 1 pabrik, bahkan mereka juga pernah melakukan pinjaman kepada mandor di pabrik. Hal tersebut sejalan dengan yang dijelaskan (Firdaus et al., 2018) bahwa strategi jaringan merupakan strategi terakhir karena mereka sebisa mungkin akan tetap berusaha sendiri tanpa meminta bantuan orang lain ketika membutuhkan uang secara mendadak, maka mereka akan meminjam uang kepada kerabat atau tetangga terdekat.

Jaringan sosial dimanfaatkan oleh keluarga buruh wanita pabrik karet sebagai salah satu alternatif dalam menghadapi tekanan-tekanan ekonomi. Pada saat tidak memiliki sumberdaya ekonomi atau kekurangan, maka mereka melakukan pinjaman kepada saudara dan tetatangga serta kepada mandor pabrik agar tetap memenuhi kebutuhan hidup sehari-harinya. Buruh wanita pabrik karet juga memanfaatkan kegiatan sosial yang ada di lingkungan sekitar seperti mengikuti arisan. Arisan yang di ikuti buruh wanita pabrik karet dengan cara melakukan pengumpulan uang dari beberapa anggota, dimana hasil arisan tersebut secara bergantian dapat dimiliki oleh setiap anggota. Arisan digunakan sebagai tabungan bagi buruh wanita pabrik karet untuk menunjang kehidupannya.

Arisan diikuti oleh buruh wanita pabrik karet yang diadakan oleh mandor pabrik karet. Hasil perolehan dari arisan akan digunakan untuk pemenuhan kebutuhan sewaktu-waktu. Arisan dilakukan setiap buruh wanita pabrik karet menerima gaji dengan jumlah uang sebesar Rp 100.000/bulan, dimana arisan ini akan dilaksanakan setiap mereka telah mendapatkan gaji. Perolehan hasil arisan yang mereka ikuti digunakan untuk pemenuhan kebutuhan sewaktuwaktu dan juga untuk membayar hutang. Hal ini sesuai dengan hasil penelitian (Jannah, 2015), yang mengatakan bahwa kegiatan arisan merupakan salah satu strategi yang paling aman untuk menyimpan maupun menggunakan uang. Bagi mereka apapun caranya, dan bagaimanapun akibatnya yang terpenting bagi mereka kebutuhan yang mereka tutupi kekurangannya bisa terpenuhi. Berdasarkan teori yang diungkapkan (Scott, 1981), maka strategi bertahan hidup jaringan sosial dapat dijelaskan pada Gambar 3. 


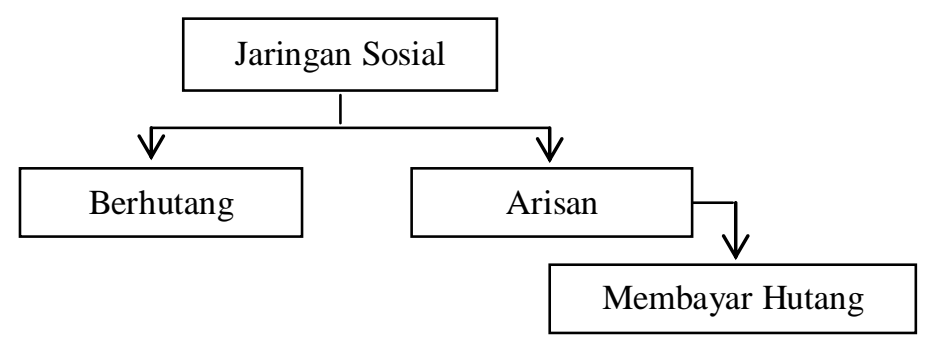

Gambar 3 Strategi Bertahan Hidup Jaringan Sosial

Strategi bertahan hidup jaringan sosial dilakukan oleh keluarga buruh pabrik karet dengan berhutang dan mengikuti arisan. Berhutang dilakukan pada saat kondisi keluarga buruh pabrik karet mempunyai kebutuhan yang mendesak dan memerlukan uang lebih. Keluarga buruh pabrik karet berhutang kepada kerabat, teman satu pabrik dan juga ke mandor. Arisan juga dilakukan guna untuk menyiapkan uang agar tidak habis secara langsung, dimana hasil dari arisan bisa digunakan untuk pemenuhan kebutuhan sewaktu-waktu dan juga untuk membayar hutang.

\section{KESIMPULAN}

Peran gender pada buruh pabrik karet di PTPN XII Kebun Mumbul didapatkan bahwa; Terdapat pembagian kerja pada buruh pabrik karet yaitu kegiatan produktif, reproduktif dan sosial. Kegiatan produktif terdiri dari pengolah karet, sortasi karet dan pengepakan karet dimana suami dan istri sama-sama berperan. Kegiatan reproduktif yang terdiri dari memasak, mencuci, belanja, mengasuh anak dan membersihkan rumah diperankan oleh istri, ada peran suami membantu mengasuh anak ketika istri sedang melakukan pekerjaan lain. Kegiatan sosial yang terdiri dari pengajian, arisan dan hajatan dilakukan oleh istri. Dalam kerangka teori struktural fungsionalisme dimana keikutsertaan istri bekerja dilakukan untuk membantu meningkatkan perekonomian keluarga sudah menjadi hal biasa di tempat penelitian dan tidak ada paksaan melainkan sudah menjadi hal yang biasa. Isu gender yang ada pada buruh pabrik karet di PTPN XII Kebun Mumbul, yaitu beban kerja lebih berat yang terjadi karena istri yang bekerja membantu suami tetapi disisi lain mereka masih mengerjakan kegiatan rumah tangga mulai dari memasak, mencuci, belanja, membersihkan rumah dan mengasuh anak.

Strategi bertahan hidup yang dilakukan keluarga buruh pabrik karet dalam kemampuan bertahan hidup dengan melakukan strategi alternatif subsistem swadaya yaitu tindakan yang dilakukan dengan kemampuan, usaha dan sumber yang dimiliki oleh keluarga buruh pabrik karet, dimana suami bekerja sebagai menggaduh kambing dan buruh tani, peran keluarga seperti istri yang bekerja sebagai buruh pabrik karet di PTPN XII Kebun Mumbul, menjadi pembantu rumah tangga dan buruh cuci. Melakukan strategi berhemat dengan menabung dan menghemat pengeluaran seperti mengurangi jatah makan serta makan seadanya dan strategi jaringan sosial dengan memanfaatkan sistem penunjang ikatan kekerabatan, pertemanan dan mandor pabrik karet untuk meminjam uang serta mengikuti arisan bulanan. Berbagai strategi tersebut dilakukan sebagai upaya dalam ketahan hidup.

\section{DAFTAR PUSTAKA}

Badan Pusat Statistik. 2016. Provinsi Jawa Timur dalam Angka. Jawa Timur. Badan Pusat Statistik Jawa Timur 
Chiari, A. 2015. Strategi Bertahan Hidup Petani saat Musim Kemarau (Studi pada Petani Sayur di Desa Tulungrejo, Kecamatan Bumiaji, Kota Batu). JMSOS, 1(1): 1-21.

Fakih, M. 1996. Analisis Gender dan Transformasi Sosial. Yogyakarta: Pustaka Pelajar.

Firdaus, D. K., S. Wahyuni dan T. Kartini. 2018. Strategi Bertahan hidup Petani Sawah Tadah Hujan untuk Pemenuhan Kebutuhan di Desa Sidodadi Kecamatan Wongsorejo Kabupaten Banyuwangi. Jurnal Ilmiah Pendidikan Ekonomi, 12(1): 1907-9990.

Handayani, T dan Sugiarti. 2006. Konsep dan Teknik Penelitian Gender. Malang: UMM Press.

Jannah, W. 2015. Strategi Bertahan Hidup Buruh Tani Sawit di Kelurahan Pasir Sialang Kecamatan Bangkinang Kabupaten Kampar. JOM FISIP, 2(1): 1-15.

Moleong, L. J. 2014. Metodologi Penelitian Kualitatif. Bandung: PT Remaja Rosdakarya.

Mosse, J. C. 1996. Gender dan Pembangunan. Terjemahan oleh Mansour Fakih. Yogyakarta: Pustaka Pelajar.

Nugraha, H. S. 2015. Strategi Bertahan Hidup Petani di Kelurahan Made Surabaya. Jurnal, 1(1): $1-20$.

Nurachmad, M. 2009. Tanya Jawab Seputar Hak-Hak Tenaga Kerja Kontrak (Outourcing). Jakarta: Transmedia Pustaka.

Pawito. 2007. Penelitian Komunikasi Kualitatif. Yogyakarta: Lembaga Kajian Islam dan Sosial (LKIS).

Pratiwi, S. M. 2018. Strategi Meningkatkan Pendapatan Wanita Mantan BuruhSadap Karet di Perkebunan PT. Glenmore. Skripsi. Jember. Fakultas Ilmu Sosial dan Ilmu Poitik Universitas Jember.

Putri, S. R. 2010. Relasi Gender pada Rumah Tangga Petani Sayuran Dataran Rendah (Kasus Rumah Tangga Petani Rawa Banteng, Desa Gempol Sari, Kecamatan Sepatan Timur, Kabupaten Tanggerang,Provinsi Banten). Skripsi. Bogor. Fakultas Ekologi Manusia Institut Pertanian Bogor.

Scott, J. C. 1981. Moral Ekonomi Petani. Jakarta: LP3ES PT Intermasa.

Sugiyono. 2015. Memahami Penelitian Kualitatif. Bandung: CV. Alfabeta.

Tarina. 2014. Mekanisme Survival Buruh Outsourcing (Studi Deskriptif tentang Strategi Bertahan Hidup Buruh Outsourcing di Sidoarjo). Skripsi. Sidoarjo. Fakultas Ilmu Sosial dan Ilmu Politik Universitas Airlangga.

Yin, R. K. 1997. Studi Kasus (Desain dan Metode). Jakarta: PT. Raja Grafindo Persada. 